\author{
PAWE⿺ NAPORA, ANNA KobrzycKa, MAREK WIECZOREK
}

Katedra Neurobiologii

Wydział Biologii $i$ Ochrony Środowiska

Uniwersytet Łódzki

Pomorska 141/143, 90-236 Eódź

E-mail: pawel.napora@unilodz.eu

marek.wieczorek@biol.uni.lodz.pl

\title{
PROSTAGLANDYNA E2 JAKO CZĄSTECZKA KOMUNIKACJI POMIE¿ZY UKŁADEM NERWOWYM I ODPORNOŚCIOWYM
}

\section{HUMORALNA DROGA KOMUNIKACJI UKŁADU NERWOWEGO Z ODPORNOSCIOWYM}

Inwazja patogenów prowadzi do zaburzenia zarówno lokalnej, jak i ogólnej homeostazy organizmu. Stan taki skutkuje aktywacja układu odpornościowego i uruchomieniem kaskady reakcji określanych mianem odpowiedzi zapalnej. Odpowiedź ta ma na celu ograniczenie rozwoju patogenu, jego unieszkodliwienie $\mathrm{i}$ usunięcie $z$ organizmu. Procesy prozapalne obejmuja między innymi syntezę szeregu substancji sygnałowych, które docierajac do OUN pozwalaja na uruchomienie centralnie kontrolowanych procesów przeciwzapalnych, zapobiegajacych nadmiernej aktywacji układu odpornościowego, prowadzacej potencjalnie do alergii lub chorób autoimmunologicznych (UFNAL i WoLYNCZYK-GMAJ 2011).

Kluczową rolę $\mathrm{w}$ utrzymaniu równowagi pomiędzy procesami pro- i przeciwzapalnymi pełni efektywna wymiana informacji pomiędzy układem odpornościowym i nerwowym. W toku ewolucji organizmy zwierzat wykształciły specyficzne mechanizmy, za pośrednictwem których OUN jest informowany o stanie wzbudzenia układu odpornościowego (SKOWRON-CENDRZAK 1993). Literatura naukowa klasyfikuje je jako mechanizmy komórkowe i humoralne (REARDON i współaut. 2018). Tak zgrupowane mechanizmy wspóltworza dwie odmienne drogi komunikacji między omawianymi układami: nerwowa $i$ humoralna. Droga nerwowa, funkcjonujaca za pośrednictwem nerwów obwodowych, reprezentowana jest m.in. przez wstępujace włókna czuciowe nerwu błędnego (KoBRZYCKA i współaut. 2017). Drogę humoralna stanowia mediatory uwalniane do płynów ustrojowych podczas wszystkich faz stanu zapalnego przez komórki immunokompetentne lub inne komórki zaangażowane w reakcje odpornościowe (monocyty, makrofagi, śródbłonek, komórki gleju oraz keranocyty) (CAEKOSIŃSKI i współaut. 2009). Mediatorami informującymi OUN o stanie wzbudzenia układu odpornościowego sa między innymi: cytokiny i prostaglandyny (BANKS 2015). Cytokiny stanowia różnorodna rodzinę glikoprotein o charakterze regulatorowym oraz pro- lub przeciwzapalnym. Posiadaja stosunkowo dużą masę cząsteczkowa, która może dochodzić nawet do około $70 \mathrm{kDa}$. Wykazuja również właściwości hydrofilowe, co wraz $z$ ich dużą masa uniemożliwia im swobodne przenikanie przez bariere krew-mózg (ang. blood-brain barrier, BBB) (DINARELLO 1999, StEnKEN i PoschenRIEDER 2015). Mimo tego według niektórych autorów cytokiny takie jak: IL-1 $\beta$, IL-6, TNF-a przekazuja do OUN za pośrednictwem kilku mechanizmów informacje o wzbudzeniu komórek odpornościowych. Pierwszym $z$ nich jest oddziaływanie cytokin na neurony, których zakończenia dendrytyczne znajduja się $\mathrm{w}$ obrębie narzadów okołokomorowych (ang. cricumventricular organs, CVO), gdzie BBB nie funkcjonuje (RIVEST 2010, BIANCARDI i STERN 2016). 
Drugim jest transport cytokin do OUN przez białkowe transportery błonowe zlokalizowane w BBB (BANKS 2015). Trzecim jest wydzielanie cytokin bezpośrednio do parenchymy mózgu przez wzbudzone komórki mikrogleju (HANSSON 2010). Czwarty mechanizm nie polega bezpośrednio na przenikaniu cytokin do OUN, lecz na wytworzeniu w jego obrębie drugorzędowego mediatora stanu zapalnego - prostaglandyny E2 $\left(\mathrm{PGE}_{2}\right)$ (ANDREASSON 2010).

Przedstawione mechanizmy podkreślaja znaczacca rolę cytokin. Warto jednak zauważyć, że podczas rozwoju stanu zapalnego, w humoralnej drodze przekazywania informacji do OUN uczestniczy także szereg innych substancji takich jak: histamina, tlenek azotu i prostaglandyny (CAŁKOSIŃSKI i współaut. 2009). W niniejszym opracowaniu chcielibyśmy przybliżyć rolę $\mathrm{PGE}_{2}$ w komunikacji pomiędzy układem nerwowym i immunologicznym.

\section{PROSTAGLANDYNY}

Prostaglandyny należą do jednej $z$ najważniejszych klas mediatorów lipidowych, eikozanoidów, które sa syntetyzowane przy udziale cyklooksygenaz, enzymów związanych $z$ prawidłowym funkcjonowaniem $\mathrm{np}$. żołądka, nerek, układu sercowo-naczyniowego, a także immunologicznego (KOEBERLE i WERZ 2015). Zwiąki te zaangażowane sa również w przebieg wielu procesów patofizjologicznych, do których zalicza się: uszkodzenia tkanek, stany zapalne i procesy nowotworzenia (SEO i OH 2017). Synteza prostaglandyn, może zachodzić w każdej komórce organizmu ssaków (FUnK 2001) i jest zależna od aktywności kompleksu enzymatycznego tworzonego przez: fosfolipazę A (PLA), syntazę cyklicznego nadtlenku prostaglandyny $\mathrm{H}$ (cyklooksygenazy, COX) oraz syntazę prostaglandyn (mikrosomalnej bądź cytozolowej, PGES). W kontekście komunikacji między układem nerwowym i odpornościowym szczególna uwagę zwraca się w kierunku cy- klooksygenaz. Jest to grupa enzymów szeroko rozpowszechnionych w tkankach ssaków (ROUZER i MARNETT 2009). Wyróżnia się dwie podstawowe izoformy COX: konstytutywna (COX-1), która jest odpowiedzialna za podstawową syntezę prostaglandyn, oraz indukowana (COX-2), której aktywność jest specyficzna dla procesów patofizjologicznych $\mathrm{m}$. in. stanów zapalnych (FUNK 2001).

OUN charakteryzuje się konstytutywnym wystepowaniem obu wspomnianych izoform cyklooksygenaz (CHANDRASEKHARAN i wspó1aut. 2002, MedeIRos i współaut. 2012). Eksperymenty przeprowadzone na myszach, $\mathrm{u}$ których inaktywowano gen odpowiedzialny za syntezę COX-2 wskazuja, że enzym ten pełni odmienna funkcje w obrębie OUN niż w tkankach obwodowych (VARDEH i współaut. 2009). W centralnej części układu nerwowego odpowiada głównie za rozwój mechanizmów związanych $z$ nadwrażliwościa na ból odczuwany podczas stanu zapalnego (FUNK 2001, VARDEH i współaut. 2009), natomiast obwodowa aktywność COX-2 odnosi się do generowania mechanizmów związanych $z$ faza ostra infekcji: indukcji zmian zachowania towarzyszacych chorobie (ang. sickness behawior) oraz goraczki (DANTZER 2009, VARDEH i współaut. 2009). Tym samym, według niektórych autorów COX-2 syntetyzuje tzw. „złe” prostaglandyny odpowiedzialne za wystapienie objawów stanu zapalnego i wzmożone odczuwanie bólu. Przeciwne właściwości wykazuje COX-1 syntetyzująca tzw. „dobre” prostaglandyny, których główna funkcja jest utrzymywanie homeostazy organizmu (Tabela 1). Doświadczenia wykonane na myszach pozbawionych genu odpowiedzialnego za syntezę COX-1 potwierdzaja także zaangażowanie tego enzymu w przebieg stanu zapalnego (FUNK 2001, PARENTE i PERRETTI 2003, VARDEH i współaut. 2009). Funkcje jakie pełni charakterystyczna dla stanów zapalnych $\mathrm{PGE}_{2}$ sa zatem zależne nie tylko od syntetyzujacej ja formy COX, ale i określonej lokalizacji w organizmie.

Tabela 1. Wybrane procesy zależne od aktywności COX-1/2. “+” istotny wpływ, “+/-“ częściowy wpływ, ““

\begin{tabular}{lcc}
\hline Proces & COX-1 & COX-2 \\
\hline Progresja stanu zapalnego & $+/-$ & + \\
Odczuwanie bólu (nocycepcja) & $+/-$ & + \\
Integralność śluzówki żołądkowo-jelitowej & + & - \\
Filtracja w kłębuszkach nerkowych & + & + \\
Synteza PGE przez komórki śródbłonka
\end{tabular}


Synteza PGE, rozpoczyna się od uwolnienia $z$ błony komórkowej kwasu arachidonowego (AA). Proces ten zachodzi pod wpływem: uszkodzenia komórki, oddziaływania specyficznej cytokiny, czynnika wzrostu lub innego bodźca, np. obecności bradykininy i trombiny w pobliżu śródbłonka (FUNK 2001). Kluczowym enzymem odpowiedzialnym za uwolnienie AA $z$ błony komórkowej jest cytozolowa fosfolipaza $\mathrm{A}_{2}$ podtypu IV (cPLA $)_{2}$ ) (FUnK 2001, SEO i OH 2017). Uwolniony podczas stanu zapalnego AA jest wykorzystywany przez syntazę prostaglandyny H (PGHS-2, nazywanej również cyklooksygenaza 2, COX-2) (FUNK 2001, ALEXANIAN i SoROKIN 2017). Powstajaca tam $\mathrm{PGH}_{2}$ zostaje przekształcona przez mikrosomalna syntazę prostaglandyny E2 (mPGES) do ostatecznej formy - $\mathrm{PGE}_{2}$ (SEO i OH 2017). Mimo że jest to szlak wiodacy i charakterystyczny dla procesów zapalnych, nie jest on jedynym prowadzacym do powstania czassteczki PGE . Synteza omawianego mediatora może odbywać się również $z$ udziałem COX-1 i cytozolowej syntazy prostaglandyny E2 (cPGES) np. w żołądku (PARK i współaut. 2006). Wyniki doświadczeń WU i NAKANISHI (2011) dostarczaja danych świadczacych o zależnym od COX-1/mPGES wzroście metabolizmu i sekrecji $\mathrm{PGE}_{2} \mathrm{w}$ OUN. Mechanizm ten indukowany jest w komórkach mikrogleju w odpowiedzi na obecność liposomów zawierajacych fosfatydyloserynę, która stanowi element strukturalny wewnętrznej części błony komórkowej (WU i NAKANISHI 2011). Uwolniona poza komórkę, może indukować rozpoznawanie i wychwytywanie komórek apoptotycznych przez makrofagi, co świadczy o potencjalnym wpływie związów proapoptotycznych na aktywność cyklooksygenaz (WU i NAKANISHI 2011).

Jak już wspomniano, $\mathrm{PGE}_{2}$ jest syntetyzowana $z$ AA uwolnionego podczas uszkodzenia tkanek, np. w skutek aktywności patogenów. Ze względu na swoje lipidowe pochodzenie, a co za tym idzie, silnie hydrofobowy charakter, prostaglandyny moga swobodnie przenikać przez błony komórkowe (YANG i CHEN 2008), co czyni je istotnymi nośnikami niespecyficznej informacji o uszkodzeniu komórek. Ponadto, czasteczki PGE moga przekraczać błonę komórkowa na drodze transportu aktywnego, przy udziale specyficznych dla prostaglandyn transporterów białkowych (FUNK 2001, NAKANISHI i TAMAI 2017). Kiedy $\mathrm{PGE}_{2}$ zostanie wydzielona $z$ produkujacej ja komórki, może wpływać na aktywność komórek układu odpornościowego. W konsekwencji wydzielają one szereg związków niezbędnych do zainicjowania procesów prozapalnych w miejscu infekcji, m.in. chemokin, cytokin, ale również kolejnych porcji $\mathrm{PGE}_{2}$, wydzielanej zwłaszcza przez makrofagi. Zwiazki te trafiają do płynów ustrojowych, w tym do krwiobiegu, gdzie $\mathrm{PGE}_{2}$ jako element drogi humoralnej bierze udział w przekazywaniu do OUN sygnału o wzbudzeniu układu odpornościowego (ABDULKHALEQ i współaut. 2018). Czassteczki PGE 2 transportowane za pośrednictwem układu krwionośnego docieraja do $\mathrm{BBB}$, a następnie przekraczaja ja i wnikaja do parenchymy mózgu (AKANUMA i współaut. 2011, SAPER i współaut. 2012).

Warto ponownie zwrócić uwage na właściwości fizykochemiczne $\mathrm{PGE}_{2}$, ponieważ $Z$ racji małego rozmiaru czasteczki oraz właściwości hydrofobowych, $\mathrm{PGE}_{2}$ może swobodnie przenikać nie tylko przez błony komórkowe, ale i takie bariery organizmu, jak BBB (DANTZER i współaut. 2000). O roli $\mathrm{PGE}_{2} \mathrm{w}$ wymianie informacji między układem nerwowym i immunologicznym świadczy fakt, iż w obrębie BBB występuja również specyficzne transportery białkowe umożliwiajacce jej bezpośredni kontakt $z$ tkanka nerwowa (KIS i współaut. 2006). Ponadto, podobnie do cytokin, $\mathrm{PGE}_{2}$ może oddziaływać na OUN poprzez CVO. Dowodem potwierdzajacym to założenie jest wynik eksperymentu OOTSUKA i współaut. (2008). Wykluczyli oni możliwość przekazywania sygnału zapalnego $z$ obwodu organizmu do OUN przez nerw błędny przez jego chirurgiczne przecięcie w odcinku szyjnym (wagotomia szyjna). Zarejestrowali, że dożylna iniekcja $\mathrm{PGE}_{2}$ indukuje goraczkę, oddziałując na ośrodek termogenezy w OUN, który znajduje się w obrębie pola przedwzrokowego (łac. area preoptica, POA) podwzgórza (OOTSUKA i współaut. 2008, SHINPO i współaut. 2012, KIECKER 2017).

W ramach komunikacji odpornościowo-nerwowej, $\mathrm{PGE}_{2}$ pełni również rolę mediatora drugorzędowego. Cytokiny uwolnione do krwiobiegu podczas wczesnych etapów rozwoju stanu zapalnego oddziałuja bowiem na komórki BBB, indukując w śródbłonku naczyń włosowatych mózgu aktywność COX2. Skutkuje to wzmożona synteza i uwalnianiem tego zwiazku do parenchymy mózgu (RIVEsT 2010, Medeiros i współaut. 2012). Ponadto, cytokiny prozapalne (np. IL-1 $\beta$ ) mają zdolność do stymulowania aktywności cyklooksygenazy nie tylko w śródbłonku, lecz także w samym OUN (DINARELLO 2002, Medeiros i współaut. 2012, WANG i współaut. 2014).

Jak już wspomniano, praktycznie wszystkie narządy zawieraja komórki wyposażone w specyficzne białka enzymatyczne odpowie-

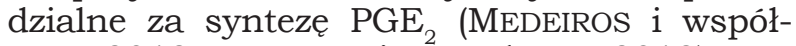
aut. 2012, LOYNES i współaut. 2018). Na uwage zasługuje jednak fakt, iż w OUN stale utrzymywane jest niewielkie stężenie prostaglandyn takich jak: $\mathrm{PGE}_{2}, \mathrm{PGD}_{2} \mathrm{i} \mathrm{PGF}_{2}$, 
co prawdopodobnie odpowiada za efektywniejsza reaktywność OUN w stosunku do czynników zaburzających stan homeostazy organizmu (VARDEH i współaut. 2009, MEdeIRos i współaut. 2012).

\section{RECEPTORY SPECYFICZNE DLA PGE 2}

Po przejściu przez BBB, $\mathrm{PGE}_{2}$ funkcjonuje jako neuromodulator $i$ tym samym wpływa na odpowiedź OUN na zagrożenia panujace na obwodzie (DANTZER i współaut. 2000). Jest to możliwe dzięki oddziaływaniu tej cząsteczki ze specyficznymi receptorami rozmieszczonymi w określonych regionach OUN (ANDREASSON 2010). Poszczególne struktury OUN charakteryzują się występowaniem odmiennych podtypów receptorów dla $\mathrm{PGE}_{2}$, a dodatkowo, gęstość ich występowania jest niejednorodna (ZHU i współaut. 2005, ANDREASSON 2010). Potwierdzono istnienie czterech podtypów receptorów, $z$ którymi $\mathrm{PGE}_{2}$ łączy się specyficznie (EP1-EP4). Zaliczane sa one do rodziny przezbłonowych receptorów metabotropowych sprzężonych $z$ białkami G. Po połączeniu $z$ ligandem wpływaja na szlaki przekazywania sygnału w komórce (YANG i CHEN 2008). Receptory EP za pośrednictwem białek G wpływaja głównie na aktywność cyklazy adenylanowej i kanałów wapniowych (Sugimoto i NARUMiYA 2007). Ze względu na sposób transdukcji sygnału podzielono je na 3 grupy. Do pierwszej $z$ nich zaliczany jest receptor EP1, którego aktywność wpływa na wzrost wewnątrzkomórkowego stężenia jonów $\mathrm{Ca}^{2+}$. Druga grupę stanowia receptory EP2 i EP4, które po aktywacji ligandem powoduja wzrost wewnatrzkomórkowego stężenia cAMP. Wszystkie te receptory zostały wykryte w zakończeniach synaptycznych (ZHU i współaut. 2005, YANG i CHEN 2008), co sugeruje ich zaangażowanie w synaptyczne procesy zwiąane $z$ neurotransmisja (YANG i CHEN 2008). Ostatnia grupa reprezentowana jest przez receptor EP3, którego aktywacja prowadzi do spadku wewnątrzkomórkowego stężenia cAMP, a w konsekwencji hamowania aktywności komórki (RIVEST 2010). Wysoka ekspresję tego podtypu receptora EP odnotowano w odpowiedzialnym za genezę gorączki polu przedwzrokowym (LAZARUS 2006). Wykazano, że $\mathrm{PGE}_{2}$ indukuje goraczkę związana ze stanem zapalnym właśnie za pośrednictwem receptorów EP3 zlokalizowanych w tym obszarze OUN. Warto nadmienić, że do indukcji goraczki dochodzi w momencie zmiany charakteru stanu zapalnego, $z$ lokalnego na ogólnoustrojowy (BLATTEIS 2007, TSUCHIYA i współaut. 2008, KIECKER 2017). Doświadczenie przeprowadzone przez TSU-
CHIYA i współau. (2008) wykazało, że u myszy pozbawionych receptorów EP3 goraczka nie rozwija się ani po obwodowym podaniu IL-1 $\beta$ lub lipopolisacharydu (LPS), elementu ściany komórkowej bakterii Gram-ujemnych, ani po ośrodkowym podaniu IL-1 $\beta$

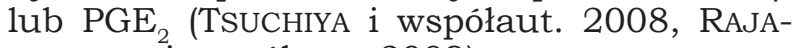
GOPALAN i współaut. 2009).

Receptory EP3 i EP4 mają wyższe powinowactwo do $\mathrm{PGE}_{2}$, co oznacza, że wymagają znacznie niższego stężenia ligandu niż EP1 i EP2, aby uruchomiona została specyficzna dla nich kaskada sygnalizacyjna (LAZARUS 2006, SANDER i współaut. 2017). Dane eksperymentalne uzyskane przez OKA i współaut. (2003) dostarczyły dowodów na występowanie wzajemnego antagonizmu pomiędzy receptorami EP3 i EP4. Autorzy badali wpływ dokomorowych iniekcji wysoko specyficznych agonistów badanych receptorów na zmiany temperatury organizmu. Zaobserwowali, że aktywacja receptora EP3 spowodowała wzrost temperatury organizmu o $1,0-1,5^{\circ} \mathrm{C}$, podczas gdy aktywacja receptora $\mathrm{EP} 4$ spadek temperatury o $0,5^{\circ} \mathrm{C}$. Badania funkcji receptorów EP3 i EP4 potwierdzaja ich antagonistyczny charakter oraz pokazuja, że temperatura organizmu stanowi wypadkowa ich aktywności (OKA i współaut. 2003, LAZARUs 2006).

\section{ODPOWIEDŹ OUN NA OBWODOWY STAN ZAPALNY}

Ośrodkowy układ nerwowy pełni niezwykle istotną rolę podczas infekcji obwodowej, koordynując pracę wszystkich systemów zaangażowanych w efektywna odpowiedź układu odpornościowego (SKOWRON-CENDRZAK 1993). W pierwszych etapach infekcji dochodzi do aktywacji komórek układu odpornościowego. Wydzielaja one do krwiobiegu mediatory stanu zapalnego, sa to np. cytokiny lub $\mathrm{PGE}_{2}$. Gdy OUN otrzyma sygnał o toczacym się na obwodzie procesie zapalnym, uruchamia mechanizmy przeciwzapalne takie jak odruch zapalny (ang. inflammatory reflex), którego elementem jest cholinergiczna ścieżka przeciwzapalna (TRACEY 2007), a także aktywacja osi podwzgórze-przysadka-kora nadnerczy (ang. hypothalamus-pituitary-adrenal axis, HPA) (DUNN 2006). Mediatory prozapalne, takie jak cytokiny pro-zapalne oraz prostaglandyny ( $z$ wyjatkiem $\mathrm{PGD}_{2}$ ), uwalniane do płynów ustrojowych podczas infekcji wpływają również na funkcjonowanie samego OUN (RIVEST 2010). Zdaniem niektórych autorów $\mathrm{PGE}_{2}$ oddziałuje na aktywność układów neurotransmisyjnych (YANG i CHEN 2008). Badania Dunna dowodzą, że dootrzewnowa iniekcja IL-1 $\beta$ powoduje w OUN wzrost stężenia głównego katabolitu nora- 


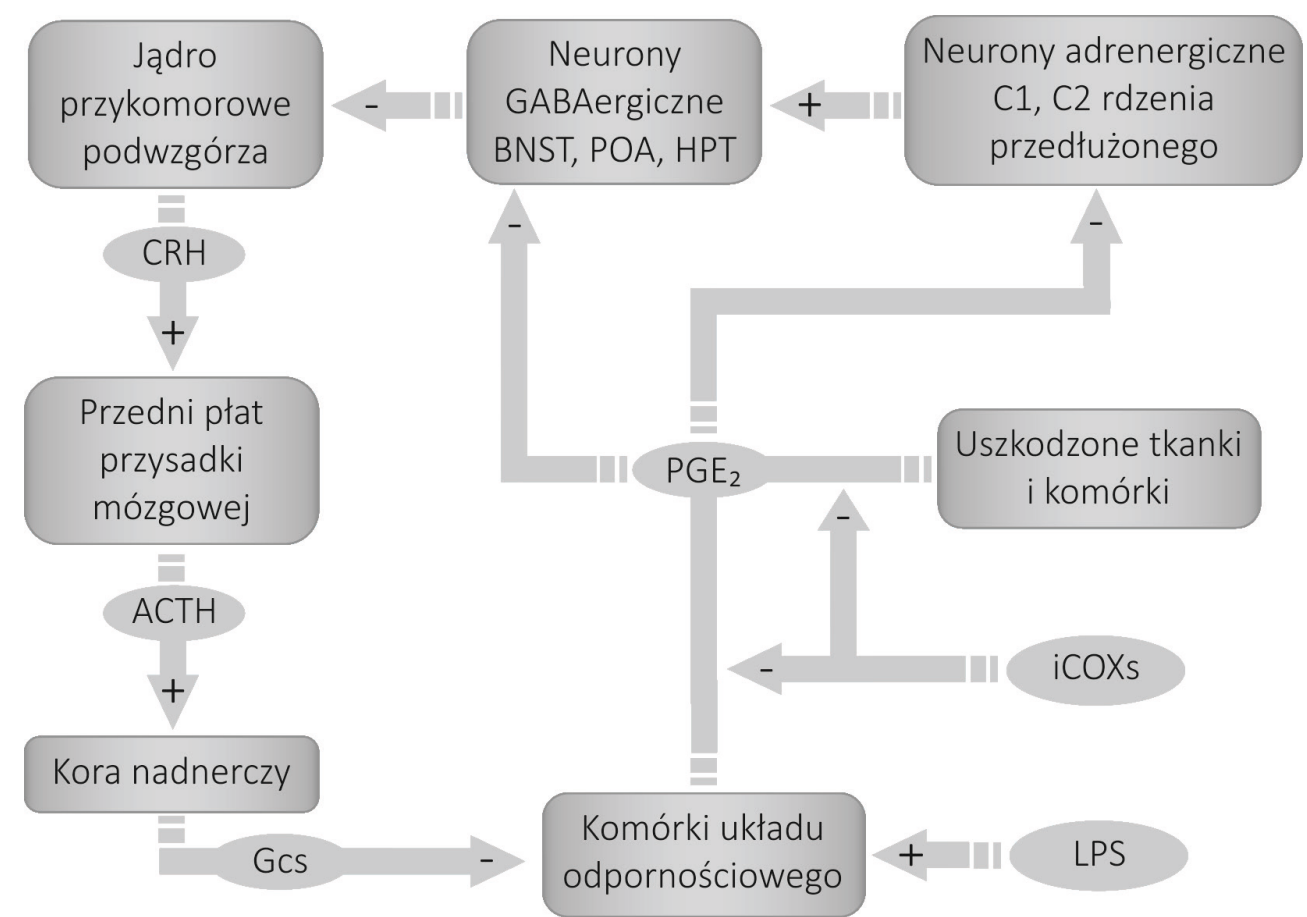

Ryc. 1. Udział inhibitorów COX w hamowaniu procesu pośredniej aktywacji osi podwzgórze-przysadka-kora nadnerczy przez prostaglandynę E2.

CRH - kortykoliberyna, ACTH - kortykotropina, Gcs - glikokortykoidy, PGE2 - prostaglandyna E2, iCOX - inhibitory cyklooksygenaz, LPS - lipopolisacharyd, BNST - neurony GABAergiczne jądra łożyskowego prążka krańcowego (łac. nucleus striae terminalis, BNST), POA - neurony GABAergiczne pola przedwzrokowego (łac. area preoptica, POA), HPT - neurony GABAergiczne podwzgórza (łac. hypothalamus).

drenaliny, którym jest 3-metoksy-4-hydroksyfenyloglikol (MHPG), przy czym największy wzrost stężenia MHPG zaobserwowany został w podwzgórzu (łac. hypothalamus, HPT). Wskazuje to, że właściwości IL-1ß pozwalaja na wzbudzenie układu noradrenergicznego w podwzgórzu, co bezpośrednio wiąże się $z$ aktywacja osi HPA (DUNN 1988, 2006). Okazuje się jednak, że oś HPA może zostać aktywowana również za pośrednictwem $\mathrm{PGE}_{2}$ (RIVEST 2010). $\mathrm{PGE}_{2}$ jako jeden $z$ mediatorów stanu zapalnego, oddziałuje $z$ receptorami EP3 zlokalizowanymi na neuronach GABA-ergicznych: jadra łożyskowego prążka krańcowego (łac. nucleus striae terminalis, BNST), pola przedwzrokowego i podwzgórza, wywierajacych hamujacy wpływ na poczatkowy element osi HPA, czyli jądro przykomorowe podwzgórza (łac. nucleus paraventri-

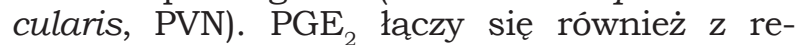
ceptorami EP3 zwiazanymi $z$ grupami neuronów adrenergicznych C1 jądra pasma samotnego (łac. nucleus tractus solitarii, NTS) oraz C2 rdzenia przedłużonego (łac. medulla oblongata), stymulujacych aktywność wspomnianych wcześniej neuronów GABA-ergicznych. Efektem tych oddziaływań jest odhamowanie aktywności PVN, które zaczyna uwalniać kortykoliberynę (CRH), hormon inicjujący przeciwzapalną aktywność osi HPA
(HERMAN i współaut. 2004, RIVEST 2010). W konsekwencji $\mathrm{PGE}_{2}$ pośrednio reguluje sekrecję glikokortykoidów $z$ kory nadnerczy, co istotnie moduluje aktywność komórek układu odpornościowego, np. podczas trwajacego stanu zapalnego (Ryc. 1). Działanie $\mathrm{PGE}_{2}$ nie ogranicza się jedynie do oddziaływania na układ noradrenergiczny w obrebie osi HPA. MARTY i współaut. (2008) wykazali, że PGE stymuluje aktywność układu glutaminergicznego w NTS, struktury, która uczestniczy w przekazywaniu znacznej liczby sygnałów czuciowych, m.in. $z$ nerwu błędnego, które następnie docieraja do wyższych pięter OUN. $\mathrm{Na}$ uwage zasługuje również fakt występowania interakcji pomiędzy układem dopaminergicznym i PGE . KITAOKA i współaut. (2007) $\mathrm{w}$ badaniach in vitro wykazali, że aktywacja receptorów D1-2 zlokalizowanych na neuronach dopaminergicznych skutkuje wzmożona synteza $\mathrm{PGE}_{2}$. Z drugiej strony, $\mathrm{PGE}_{2}$ przez oddziaływanie $z$ receptorem EP1 na powierzchni neuronów dopaminergicznych wpływa na wzmocnienie transmisji dopaminergicznej. Dane te uzyskano analizujac zależności między układem dopaminergicznym i prostaglandyna E2 w skrawkach prążkowia (łac. striatum), struktury OUN regulujacej funkcje ruchowe, poznawcze i emocjonalne (KITAOKA i współaut. 2007). Ciekawe obser- 
wacje odnośnie $\mathrm{PGE}_{2}$ i układu dopaminergicznego przedstawili KOBRZYCKA i współaut. (2019). Autorzy zaobserwowali, że przecięcie nerwu błędnego, elementu neuronalnej drogi komunikacji układu odpornościowego z OUN, skutkuje wzrostem metabolizmu w wielu strukturach mózgowia, również tych należacych do układu limbicznego. Warto nadmienić, że podczas rozwijającej się infekcji u zwierząt poddanych wspomnianemu zabiegowi, poziom $\mathrm{PGE}_{2} \mathrm{~W}$ osoczu był znamiennie wyższy niż u zwierząt kontrolnych, a podniesiony wcześniej metabolizm dopaminy uległ normalizacji (KOBRZYCKA i współaut. 2019). Autorzy zasugerowali również, że zwiększony poziom $\mathrm{PGE}_{2}$ podczas infekcji może być swoistym mechanizmem kompensujacym brak możliwości detekcji patogenów i molekuł $z$ nimi zwiazanych. Jednocześnie może on kompensować brak regulacyjnych, względem układu odpornościowego, funkcji nerwu błędnego, który może pojawiać się w takich sytuacjach jak neuropatie cukrzycowe (KOBRZYCKA i współaut. 2019).

Wpływ $\mathrm{PGE}_{2}$ na działanie układu neuroendokrynnego i szlaków neurotransmisyjnych, zwłaszcza w obrębie struktur układu limbicznego zwiazanych $z$ kontrolą stanów emocjonalnych, znajduje potwierdzenie również w zachowaniu chorych zwierzat. Występujacy podczas choroby zespół specyficznych zachowań i objawów takich jak: obniżenie aktywności lokomotorycznej, zmniejszenie ilości pobieranych płynów i pokarmu, nadwrażliwość na ból, brak odczuwania przyjemności, określone wspólnym mianem sickness behavior (zachowania chorobowe), koreluje ze zwiększonym stężeniem $\mathrm{PGE}_{2}$ w OUN (SOSZYŃSKI 2004, KITAOKA i współaut. 2007, PECCHI i współaut. 2009). Zaangażowanie COX oraz jej produktów w genezę sickness behavior potwierdzają również dane uzyskane przez DE PAIVA i współaut. (2010). Badacze ci zaobserwowali, że dootrzewnowa iniekcja nieselektywnego (indometacyna) i selektywnego (nimesulid) inhibitora COX-2 zapobiega wystapieniu sickness behavior spowodowanego podaniem LPS. Wśród zwierzat, które otrzymywały inhibitory COX podanie LPS nie spowodowało: obniżenia aktywności lokomotorycznej, zmniejszenia ilości pobieranego pokarmu i obniżenia masy ciała.

Wzrost stężenia PGE podczas rozwoju stanu zapalnego jest ściśle zwiazany nie tylko $z$ lokalnym uszkodzeniem komórek i aktywacja komórek odpornościowych, ale też ze wspomniana już ośrodkowa indukcją gorączki i pogorszeniem samopoczucia. $\mathrm{PGE}_{2}$, syntetyzowana $\mathrm{w}$ odpowiedzi na czynniki prozapalne, należy bowiem wiąać również $z$ odczuwaniem bólu (nocycepcja). Nocycepcja i stan zapalny to procesy ściśle zwiazane ze wzmożoną aktywnością cyklooksygenaz, zarówno formy konstytutywnej (COX-1), jak i indukowanej (COX-2) (GRÖSCH i współaut. 2017). PGE jest dobrze poznanym mediatorem bodźców nocyceptywnych, co więcej, pełni kluczową rolę w powstawaniu stanów przewlekłego bólu. Powodowane przez $\mathrm{PGE}_{2}$ przedłużające się uwrażliwienie neuronów znajdujących się w nocyceptywnym zwoju korzeni grzbietowych (ang. dorsal root ganglion, DRG) może przyczynić się do przejścia formy ostrej bólu w formę przewlekłą. Dodatkowo, długotrwałe oddziaływanie $\mathrm{PGE}_{2}$ na DRG może doprowadzić do wystapienia zjawiska allodynii, czyli stanu, w którym organizm odczuwa ból w odpowiedzi na bodźce $z$ nim nie zwiazane (ST-JACQUES i MA 2014). Badania ST-JACQUES i MA (2014) wskazuja istotne zaangażowanie $\mathrm{PGE}_{2} \mathrm{w}$ procesy związane $z$ uwrażliwieniem organizmu na bodźce bólowe. W swoim doświadczeniu wykazali, że po podaniu stabilnej formy $\mathrm{PGE}_{2}$ (16,16-dimetylo-PGE , dmPGE $_{2}$ u szczurów rozwija się allodynia, trwajaca 24h. Natomiast w

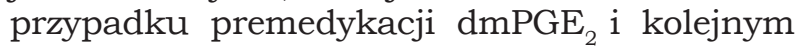
podaniu dawki wywołujacej allodynię, efekt zjawiska utrzymywał się 4 dni.

\section{REGULACJA AKTYWNOŚCI ENZYMATYCZNEJ CYKLOOKSYGENAZ}

Głównym źródłem prostanoidów w OUN jest tkanka glejowa. Początkowo uważano, że niemal wszystkie prostanoidy w OUN sa syntetyzowane i uwalniane przez astrocyty, jednak późniejsze badania wykazały, że to mikroglej odpowiada za uwalnianie do parenchymy mózgu większej ilości tych związków (Medeiros i współaut. 2012). Dominujący udział mikrogleju w ośrodkowej syntezie PGE potwierdza fakt, iż w aktywowanym dootrzewnowym podaniem LPS mikrogleju zaobserwowano szczególnie zwiększona ilość enzymu COX-2 (MinGHeTti i LEVI 1998, MinghetTI i POCCHIARI 2007). LPS nie jest jednak jedynym czynnikiem regulujacym poziom syntetyzowanej $\mathrm{PGE}_{2}$. Istnieje bowiem szereg endogennych substancji, które wpływają na aktywność enzymów zwiazanych $z$ synteza $\mathrm{PGE}_{2}$. W obrębie OUN potwierdzono obecność czynników wywierajacych wpływ na aktywność COX-2. Sa to między innymi hormony stresu, glikokortykoidy (LEVI i współaut. 1998, MASON i współaut. 2010), oraz mediatory o charakterze przeciwzapalnym, których przykładem jest IL-10 (LEVI i współaut. 1998, STRLE i współaut. 2001). Dodatkowo, do czynników regulujących aktywność COX-2 zalicza się lipokortynę, białko, które hamuje syntezę $\mathrm{PGE}_{2}$ przez blokowanie aktywności fosfolipazy $\mathrm{A}_{2}$, enzymu limitującego liczbę cząsteczek kwasu arachi- 
donowego uwalnianych $\mathrm{z}$ błony komórkowej (LEVI i współaut. 1998, MINGHETTI i wspó1aut. 1999). Wszystkie wymienione związki wpływaja negatywnie na aktywność COX2. Działanie przeciwne wykazuja cytokiny prozapalne: TNF-a i IL-1 $\beta$ (LEVI i wspó1aut. 1998, NAM i współaut. 2003, BLATTEIS i współaut. 2005), oraz neuroprzekaźniki: noradrenalina i glutaminian (STRAUSS 2008, SCHLACHETZKI i współaut. 2010). Ciekawa interakcja zachodzi również między jednym $z$ końcowych produktów aktywności COX-2 a nią samą. Okazuje się bowiem, że $\mathrm{PGE}_{2}$ pełni rolę pozytywnego regulatora aktywności COX-2 (MingheTTI i współaut. 1997).

Wiadomo również, że w środowisku zewnętrznym organizmu występuja substancje stymulujace aktywność cyklooksygenaz i tym samym wpływające na zwiększenie produkcji $\mathrm{PGE}_{2}$. Dobrze poznanym egzogennym zwiąkiem wykazujacym takie działanie jest LPS. Warto nadmienić, iż jego oddziaływanie nie ogranicza się jedynie do indukowania aktywności COX-2, lecz dodatkowo prowadzi do podniesienia jej ekspresji, np. w komórkach nabłonkowych zaangażowanych w procesy odpornościowe (BRITT i współaut. 2012). Kolejnym egzogennym zwiazkiem oddziałującym na ekspresje genów dla COX-2 jest enterotoksyna gronkowca B (ang. staphylococcal enterotoxin B, SEB). Zwiazek ten jest syntetyzowany przez niektóre bakterie Gram-dodatnie i zaliczany do superantygenów. Powoduje on wzrost ekspresji genów odpowiedzialnych za syntezę COX-2 w mysich limfocytach T (RAJAGOPALAN i współaut. 2009).

Oprócz wspomnianych już regulatorów aktywności cyklooksygenaz, zarówno endo-, jak i egzogennych, istnieje szereg substancji zaliczanych do grupy tzw. niesteroidowych leków przeciwzapalnych (NLPZ). Substancje te stanowią grupę egzogennych związków hamujacych syntezę $\mathrm{PGE}_{2}$ przez ograniczenie aktywności COX. W konsekwencji, NLPZ wykazuja działanie nie tylko przeciwzapalne, ale też przeciwbólowe i przeciwgoraczkowe. Klasyfikacji NLPZ można dokonać w oparciu o powinowactwo do określonych form cyklooksygenaz. Na tej podstawie wyróżnia się nieselektywne i selektywne inhibitory COX (Tabela 2). Związki należące do pierwszej grupy hamuja aktywność zarówno COX-1, jak i COX-2. Zwiazki zaliczane do drugiej grupy charakteryzuja się natomiast selektywnym hamowaniem aktywności COX-2 lub częściowo selektywnym hamowaniem COX-1 (BotTing 2010, CARUllo i współaut. 2017). NLPZ są szczególnie ważne, ponieważ, ze względu na ich szerokie rozpowszechnienie oraz brak wymogu posiadania recepty, stanowią grupę leków najczęściej stosowa- nych obecnie w medycynie. W wyniku tego, wśród ludności krajów rozwiniętych, obserwuje się zjawisko epidemii nadużywania NLPZ. Blisko 35 milionów ludzi na całym świecie codziennie stosuje te leki, co stanowi poważne zagrożenie; u wielu osób NLPZ moga one wywoływać reakcje nadwrażliwości, a ponadto moga wchodzić $\mathrm{w}$ reakcje $\mathrm{Z}$ innymi lekami (KowALSKI i współaut. 2011, REGUŁA i współaut. 2011). Nadużywanie, w szczególności nieselektywnych inhibitorów COX, prowadzić może do wystapienia objawów niepożądanych, a następnie do rozwoju licznych chorób (ABBOTT i FRASER 1998, FOKUNANG i współaut. 2018). Jak się okazuje, długotrwałe hamowanie aktywności COX-1 powoduje uszkodzenie błony śluzowej żołąka, co $z$ kolei stanowi korzystne środowisko dla rozwoju choroby wrzodowej. W przypadku nerek, przewlekłe stosowanie inhibitorów COX-1 wywołuje zmiany hemodynamiczne, które moga wywoływać ich niewydolność. W układzie sercowo-naczyniowym przewlekła inhibicja aktywności COX-1 prowadzi do powstania zmian naczyniowych skutkujących nadciśnieniem, obrzękiem, a nawet niewydolnością serca (WALLACE 2000, FOKUnANG i współaut. 2018). Przewlekłe hamowanie aktywności COX-2 przez selektywne formy inhibitorów może również prowadzić do wystapienia efektów niepożądanych, a nawet chorób. Wynika to $z$ faktu, iż zwiąki te hamujac aktywność COX-2, której obecność potwierdzono w niektórych narzadach wewnętrznych (np. w nerkach). Zatem objawy niepożądane występujace podczas stosowania selektywnych inhibitorów COX2 sa prawdopodobnie wynikiem hamowania syntezy $\mathrm{PGE}_{2} \mathrm{w}$ obszarach organizmu, w których pełni ona funkcje homeostatyczne. Oczywiście ryzyko wystapienia takich efektów jest znacznie mniejsze niż w przypadku przewlekłego stosowania form nieselektywnych (HARRIS 2000, WRIGHT 2002, SHAHRASBI i współaut. 2018).

Badania przeprowadzone przez WooDLING i współaut. (2016) dostarczaja danych potwierdzajacych wpływ stosowania nieselektywnych inhibitorów COX na układy neurotransmisyjne w OUN. Wykorzystujac chromatografię cieczową wykazali, że długotrwałe podawanie ibuprofenu powoduje istotny wzrost stężenia dopaminy $\mathrm{w}$ formacji hipokampa myszy. Dodatkowo, przeprowadzając analizy $z$ wykorzystaniem mikromacierzy cDNA i metody real-time qPCR potwierdzili, że długotrwałe stosowanie ibuprofenu skutkuje wzrostem ekspresji genów kodujacych receptor dopaminowy D1 oraz peptyd prekursorowy met-enkefaliny - pre proenkefalinę. Analiza danych pozyskanych przez LiN i współaut. (2014) także potwierdza istnie- 
Tabela 2. Wpływ wybranych inhibitorów cyklooksygenaz na aktywność COX-1/2 (wg PERRONE i współaut. 2010, RIMON i współaut. 2010, WORON i współaut. 2011, SAMBORSKi i współaut. 2017).

\begin{tabular}{|c|c|c|}
\hline Inhibitory & Opis & Substancja \\
\hline $\begin{array}{l}\text { Częściowo selektywne inhibi- } \\
\text { tory COX-1 }\end{array}$ & $\begin{array}{l}\text { Charakteryzujące się istotnie wyższym } \\
\text { powinowactwem do COX-1 niż do COX-2. }\end{array}$ & $\begin{array}{l}\text { SC-560, FR122047, kwas acetylosalicy- } \\
\text { lowy (w małych dawkach) }\end{array}$ \\
\hline $\begin{array}{l}\text { Nieselektywne } \\
\text { COX-1 }\end{array}$ & $\begin{array}{l}\text { Wykazujące wyższe powinowactwo do } \\
\text { COX-1 niż do COX-2. }\end{array}$ & $\begin{array}{l}\text { ibuprofen, ketaprofen, naproksen, in- } \\
\text { dometacyna }\end{array}$ \\
\hline $\begin{array}{l}\text { Preferencyjne inhibitory } \\
\text { COX-2 }\end{array}$ & $\begin{array}{l}\text { Wykazujące wyższe powinowactwo do } \\
\text { COX-2 niż do COX-1. }\end{array}$ & meloksykam, nimesulid \\
\hline Selektywne inhibitory COX-2 & $\begin{array}{l}\text { Charakteryzujace się około } 200 \text { razy wyż- } \\
\text { szym powinowactwem do COX-2 niż do } \\
\text { COX- } 1 \text {. }\end{array}$ & celekoksyb, parekoksyb, etorykoksyb \\
\hline
\end{tabular}

nie zależności pomiędzy stosowaniem inhibitorów COX a zmianą aktywności układów neurotransmisyjnych. Autorzy opisali hamujaccy wpływ selektywnego inhibitora COX-2 (celekoksybu) na uwalnianie glutaminianu przez zakończenia nerwowe w korze mózgu szczura. Wyniki uzyskane przez WoODLING i współaut. (2016) oraz LiN i współaut. (2014) wskazują na zależność między zablokowaniem syntezy $\mathrm{PGE}_{2}$ a zmiana aktywności układów neurotransmisyjnych, dopaminergicznego i glutaminergicznego. Pozwala to przypuszczać, iż inaktywacja szlaku sygnałowego drogi humoralnej (szlak $\mathrm{PGE}_{2} / \mathrm{COX}$ ) może prawdopodobnie indukować zmiany funkcjonalne w drodze alternatywnej - neuronalnej. Przypuszczenie to potwierdzaja dane dotyczace wpływu inhibitorów COX na NTS. Zahamowanie aktywności COX-2 podczas trwajacego na obwodzie stanu zapalnego nie zapobiega bowiem wzrostowi ekspresji białka c-Fos, markera aktywności neuronów, w NTS, jądrze czuciowym nerwu błędnego. Okazuje się jednak, że inhibicja aktywności COX-1 w tej samej sytuacji powoduje zablokowanie wzrostu ekspresji białka c-Fos w NTS (ZHANG i współaut. 2003). Świadczy to o zaangażowaniu $\mathrm{PGE}_{2} \mathrm{w}$ regulację procesów zwiazanych $z$ detekcją patogenów zachodzacych za pośrednictwem wstępujacych włókien czuciowych nerwu błędnego. Dodatkowo wyniki eksperymentu ZHANG i współaut. (2003) potwierdzaja wpływ $\mathrm{PGE}_{2}$ na aktywność neuronów zwiąana bezpośrednio $z$ aktywnością układów neurotransmisyjnych (FLAVELL i GREENBERG 2008). W celu poparcia tego założenia porównano dane pochodzace $z$ doświadczenia ZHANG i współaut. (2003), WoODLING i współaut. (2016) oraz LIN współaut. (2014). Dane te koreluja ze soba i pokazuja, że PGE wpływa zarówno na ekspresję białka c-Fos, jak i aktywność układu dopaminergicznego i glutaminergicznego.

Możliwość występowania interakcji pomiędzy droga neuronalna i humoralna sugeruje prawdopodobne istnienie swoistych mechanizmów odpowiedzialnych za przejmowanie funkcji uszkodzonej drogi przez tę, która jest w pełni sprawna (WoODLING i współaut. 2016, KOBRZYCKA 2017).

\section{COX-2 I CHOROBY O PODŁOŻU NEURODEGENERACYJNYM}

Współczesne badania coraz częściej wskazują na istotna rolę COX-2 i jej produktów w patogenezie wielu chorób zwierząt (FITZGERALD 2003, MAINGRET i współaut. 2017, IKEDA-MATSUO 2019). Patologiczne zmiany ekspresji tego enzymu sa obserwowane w przypadku chorób zlokalizowanych zarówno na obwodzie, jak i w centralnej części układu nerwowego (FITZGERALD 2003, MingheTTI i POCCHIARI 2007). Okazuje się, że zwiększony poziom białka COX-2 oraz zwiększona synteza $\mathrm{PGE}_{2} \mathrm{w}$ OUN zostały opisane w chorobach: Alzheimera (AD), Parkinsona (PD) i stwardnieniu rozsianym (SM) (TEISMANN i współaut. 2003, MAINGRET i współaut. 2017, PALUMBO 2017). Badania JoHANSSON i współaut. (2015) wskazują, że szlak COX2/PGE2, wraz $z$ aktywacją receptorów EP4, odgrywa istotna rolę $\mathrm{w}$ rozwoju AD. Stan zapalny indukowany przez $\mathrm{PGE}_{2}$ stymuluje powstawanie białkowych złogów $\beta$-amyloidu, stanowiacych czynnik toksyczny dla OUN w przebiegu tej choroby (Hoshino i współaut. 2009, JOHANSSON i współaut. 2015). W przypadku PD zwiększona ilość COX-2 koreluje Z charakterystycznymi obszarami objętymi procesami neurodegeneracyjnymi. Prawdopodobnie, zwiększona synteza $\mathrm{PGE}_{2}$ w obrębie struktur szlaku czarno-prażkowiowego nasila ich uszkodzenia będące wynikiem postępują- 
cych procesów neurodegeneracyjnych w PD (TEISMANN i współaut. 2003, IKEDA-MATSUO 2019). Również podczas pośmiertnych badań mózgu pacjentów $z$ SM stwierdzono zmiany dotyczące aktywności szlaku COX-2/PGE2; zwiększona aktywność COX-2 została opisana w częściach OUN objętych aktywnym procesem demielinizacyjnym i w umierajacych oligodendrocytach (CARLSON i współaut. 2010, PALUMBO 2017). Opisane mechanizmy wskazuja, że zwiększona aktywność COX2 jest elementem wspólnym dla AD, PD, SM, co uzasadnia fakt stosowania NLPZ w terapii przedstawionych chorób neurodegeneracyjnych mózgu (JOHANSSON i współaut. 2015, PALUmbo 2017, Ren i współaut. 2018). Zwiększona ilość COX-2 i wzmożona synteza $\mathrm{PGE}_{2}$ stanowią potencjalne czynniki współodpowiedzialne za rozwój i progresję chorób neurodegeneracyjnych. Zidentyfikowanie czynników wpływajacych na wzrost syntezy $\mathrm{PGE}_{2}$ umożliwi prawdopodobnie skuteczniejszą terapię wyżej wymienionych chorób.

\section{PODSUMOWANIE}

Przedstawione informacje i wyniki badań pozwalaja na sformułowanie hipotezy dotyczącej komunikowania się układu odpornościowego $z$ OUN. Współdziałanie układu odpornościowego $z$ OUN wymaga istnienia wyspecjalizowanych mechanizmów zapewniajacych skuteczna wymianę informacji pomiędzy nimi. Dlatego organizm zwierząt, w tym człowieka, jest zdolny do syntezy i wydzielania do płynów ustrojowych szeregu zwiąków sygnałowych. Do ich detekcji dochodzi za pośrednictwem specyficznych dla nich receptorów obecnych na komórkach obu układów. Niezwykle istotnymi dla procesu komunikacji między omawianymi układami sa produkty aktywności enzymatycznej COX-2, w szczególności PGE (DANTzER i współaut. 2000). Powszechne występowanie COX-2 zapewnia możliwość syntezy $\mathrm{PGE}_{2}$ w każdej tkance organizmu objętej działaniem czynnika szkodliwego. Wskazuje to na uniwersalna rolę $\mathrm{PGE}_{2} \mathrm{w}$ generowaniu informacji o zagrożeniu homeostazy organizmu (MEDEIROS i współaut. 2012, LOYNES i współaut. 2018). Hydrofobowy charakter oraz obecność transporterów białkowych w błonach komórkowych powoduja, że czassteczka $\mathrm{PGE}_{2}$ charakteryzuje się silna penetracja wszelkich barier organizmu (KIS i współaut. 2006, BANKS 2015). Ponadto, w celu przekazania informacji do OUN wykorzystuje również pośrednie mechanizmy przenikania przez BBB. Jest to między innymi indukcja aktywności COX-2 w śródbłonku, czego następstwem jest synteza i uwolnienie kolejnych porcji $\mathrm{PGE}_{2}$ do parenchymy mózgu (MingheTTI i współaut.
1997). Kolejnym pośrednim mechanizmem pokonywania $\mathrm{BBB}$ jest oddziaływanie na komórki nerwowe w obrębie narządów okołokomorowych (BLATTEIs i współaut. 2005). Następstwem kontaktu cząsteczki PGE $_{2}$ Z neuronami jest przekazanie informacji o działaniu czynnika szkodliwego. Odbywa się to za pośrednictwem specyficznych dla $\mathrm{PGE}_{2}$ receptorów EP zlokalizowanych na komórkach nerwowych (LAZARUS 2006, SANDER i współaut. 2017). Ich obecność potwierdzono w wielu strukturach OUN zwiazanych $z$ wykrywaniem obecności patogenów lub wpływajacych na pracę układu odpornościowego: POA, PVN, CVO i centralnym jądrze ciała migdałowatego (PECCHI i współaut. 2009, ANDREASSON 2010). Zależnie od typu aktywowanego receptora $\mathrm{EP}$, efekt działania $\mathrm{PGE}_{2}$ może obejmować spadek lub wzrost aktywności komórki nerwowej (RIVEST 2010). Konsekwencja hamowania aktywności komórek nerwowych za pośrednictwem receptorów EP3 w POA jest geneza goraczki (BLATTEIS 2007, KIECKER 2017). Jest to skuteczny mechanizm walki $z$ infekcja, który nie tylko ogranicza wzrost i rozwój patogenów, ale i stymuluje proliferację komórek odpornościowych (PECCHI i współaut. 2009). W odpowiedzi na stan zapalny, dochodzi do wzrostu stężenia $\mathrm{PGE}_{2} \mathrm{w}$ obrębie OUN. Sygnał ten indukuje zmniejszenie ilości pobieranego pokarmu i depresję behawioralna, jedne $z$ głównych elementów sickness behavior (DANTZER 2009, PECCHI i współaut. 2009). Dowodem na zaangażowanie $\mathrm{PGE}_{2} \mathrm{w}$ indukcję wspomnianych mechanizmów obronnych jest fakt, iż stosowanie selektywnych inhibitorów COX-2 osłabia ich przebieg lub nawet zapobiega ich uruchomieniu (BLATTEIS i współaut. 2005, PECCHI i współaut. 2009). Ponadto, badania ZHANG i współaut. (2003) wskazuja na odmienna rolę 1 i 2 izoformy cyklooksygenazy w przekazywaniu sygnału o stanie zapalnym do OUN i indukcji c-Fos w obrębie NTS. Reasumując, $\mathrm{PGE}_{2}$ jest niezwykle ważnym nośnikiem informacji między wzbudzonym układem odpornościowym a OUN. Wykazuje wiele właściwości pozwalających jej na skuteczne przekazywanie informacji o zaburzeniu homeostazy organizmu. OUN posiada specyficzne receptory w strukturach odpowiedzialnych za procesy związane $z$ wykrywaniem obecności patogenów oraz regulujacych aktywność układu odpornościowego, co wskazuje, że $\mathrm{PGE}_{2}$ posiada zdolność do modulowania aktywności tych obszarów. Co więcej, wykazuje ona również wpływ na aktywność całych układów neurotransmisyjnych, czego efektem może być indukcja zmian dotyczacych innych obszarów życia osobnika, np. zachowania, motoryki lub odczuwania przyjemności. 
Niezwykle istotna dla utrzymania stanu homeostazy organizmu jest właściwa ekspresja genów dla COXs oraz kontrola ich optymalnego poziomu translacji, a także aktywności enzymatycznej białek. Zaburzenia mechanizmów regulujących aktywność COX-1 i 2 moga prowadzić do wystapienia chorób zlokalizowanych zarówno na obwodzie, jak i w OUN (MinghetTi 2004, Husband i MeHTA 2013). Wzmożona ekspresja COX-2 obserwowana jest podczas wielu schorzeń obwodowych, wśród których wyróżnia się np. zaburzenia naczyniowe (zakrzepicę miażdżycowa) lub schorzenia stawów (artretyzm) (CIPOLlONE i FAZIA 2006, KIM i współaut. 2016). W obrębie OUN wyższy poziom COX-2 związany jest $z$ występowaniem schorzeń neurodegeneracyjnych takich jak: stwardnienie rozsiane, choroba Alzheimera lub Parkinsona. W celu zwalczania objawów wymienionych chorób stosowane sa zwiazki $z$ szerokiej grupy inhibitorów cyklooksygenaz, przy czym skuteczniejsze sa specyficzne inhibitory COX-2, hamujące aktywność indukowanej formy COX. Niestety wciąż wiele osób w sposób niekontrolowany korzysta $z$ przeciwzapalnych i przeciwbólowych właściwości nieselektywnych inhibitorów COX, hamujących nie tylko aktywność formy indukowanej, ale i konstytutywnej (TEISMAnN i współaut. 2003, MAINGRET i współaut. 2017, PALUMBO 2017). Zwiazki te skutecznie niweluja stany zapalne i zwiazany z nimi ból, lecz oddziałuja również negatywnie na homeostazę wielu narzadów wewnętrznych. Co więcej, ich długotrwałe stosowanie, np. w przypadku przewlekłego bólu, może doprowadzić do wystapienia objawów niepożądanych, tj. wrzodów żołądka, niewydolności nerek, a nawet chorób sercowo-naczyniowych (WALLACE 2000, FOKUNANG i współaut. 2018, SHAHRASBI i współaut. 2018). Z perspektywy komunikacji układu odpornościowego i OUN dhugotrwałe stosowanie inhibitorów COX jest niekorzystne, ponieważ PGE wydzielana przez komórki układu odpornościowego pełni rolę ważnego mediatora stanu zapalnego. Indukuje ona szereg mechanizmów obronnych, takich jak goraczka i sickness behavior, które maja na celu unieszkodliwienie obecnych w organizmie patogenów. W sytuacji, gdy aktywność COX jest stale hamowana, układ odpornościowy nie może skutecznie przekazywać do OUN informacji o zagrożeniu i tym samym nie dochodzi do prawidłowej indukcji wspomnianych mechanizmów obronnych (LI i współaut. 2001, DE PAIVA i współaut. 2010). W konsekwencji może to prowadzić do progresji istniejących chorób w wyniku maskowania ich objawów.

\section{Streszczenie}

Wymiana informacji pomiędzy wzbudzonym układem odpornościowym a ośrodkowym układem nerwowym
(OUN) zapewnia utrzymanie stanu homeostazy organi$z m u$. Jedną $z$ głównych dróg odpowiedzialnych za wspomniana komunikację jest droga humoralna. Reprezentuja ja związki uwalniane przez komórki odpornościowe i uszkodzone tkanki. Czasteczkami istotnie zaangażowanymi we wspomniany proces komunikacji sa prostaglandyny, szczególnie prostaglandyna E2 $\left(\mathrm{PGE}_{2}\right)$, powstająca $\mathrm{w}$ wyniku aktywności cyklooksygenaz. $\mathrm{PGE}_{2}$ penetruje wszelkie bariery organizmu, w tym barierę krew-mózg, a co więcej, w OUN potwierdzono obecność specyficznych dla niej receptorów. Za ich pośrednictwem PGE moduluje aktywność układów neurotransmisyjnych w OUN, co w konsekwencji indukuje złożone mechanizmy odpornościowe. Ostatecznie dochodzi do skutecznej neutralizacji infekcji, przy jednoczesnym hamowaniu aktywności nadmiernie wzbudzonego układu odpornościowego. Efekty wywoływane przez $\mathrm{PGE}_{2}$ ulegaja osłabieniu lub całkowitemu zniesieniu przez zastosowanie określonych inhibitorów cyklooksygenaz. Niniejsza praca stanowi podsumowanie obecnych wiadomości dotyczacych procesów wymiany informacji pomiędzy wzbudzonym układem odpornościowym a OUN za pośrednictwem $\mathrm{PGE}_{2}$.

\section{LITERATURA}

AввоTT F. V., FRASER M. I., 1998. Use and abuse of over-the-counter analgesic agents. J. Psychiatr. Neurosci. 23, 13-34.

ABDulKhaleQ L. A., ASSi M. A., ABDullah R., ZAMRI-SAAD M., TAUFIQ-YAP Y.'H., HEZMEE M. N. M., 2018. The crucial roles of inflammatory mediators in inflammation: A review. Vet. World 11, 627-635.

AKANUMA S. I., UCHIDA Y., OHTSUKI S., TACHIKAWA M., Terasaki T., Hosoya K. I., 2011. Attenuation of prostaglandin $E 2$ elimination across the mouse blood-brain barrier in lipopolysaccharide-induced inflammation and additive inhibitory effect of cefmetazole. Fluids Barriers CNS 8, 1-12.

ALEXANIAN A., SOROKIN A., 2017. Cyclooxygenase 2: protein-protein interactions and posttranslational modifications. Physiol. Genomics 49, 667-681.

ANDREASSON K., 2010. Emerging roles of PGE2 receptors in models of neurological disease. Prostaglandins Other Lipid Mediat. 91, 104112

BANKS W. A., 2015. The blood-brain barrier in neuroimmunology: tales of separation and assimilation. Brain Behav. Immun. 44, 1-8.

BIANCARDI V. C., Stern J. E., 2016. Compromised blood-brain barrier permeability: novel mechanism by which circulating angiotensin II signals to sympathoexcitatory centres during hypertension. J. Physiol. 594, 1591-1600.

BLATTEIS C. M., 2007. The onset of fever: new in sights into its mechanism. Progr. Brain Res. $162,3-14$

Blatteis C. M., Li S., Li Z., Feleder C., Perlik V., 2005. Cytokines, PGE2 and endotoxic fever: a re-assessment. Prostaglandins Other Lipid Mediat. 76, 1-18.

BotTING R. M., 2010. Vane's discovery of the mechanism of action of aspirin changed our understanding of its clinical pharmacology. Pharmacol. Rep. 62, 518-525.

BRITT JR R. D., LOCY M. L., TIPPLE T. E., NELIN L. D., ROGERS L. K., 2012. Lipopolysaccharide-induced cyclooxygenase-2 expression in mouse transformed Clara cells. Cell. Physiol. Biochem. 29, 213-222. 
CARLSON N. G., ROJAS M. A., REDD J. W., TANG P., Wood B., Hill K. E., Rose J. W., 2010. Cyclooxygenase-2 expression in oligodendrocytes increases sensitivity to excitotoxic death. J. Neuroinflam. 7, 1-11.

CAŁKOSIŃSKI I., DOBRZYŃSKI M., CAŁKOSIŃSKA M., SEWERYN E., BRONOWICKA-SZYDEEKO A. DZIERZBA K., GAMiAn A., 2009. Charakterystyka odczynu zapalnego. Post. Hig. Med. Dośw. 63, 395-408.

Carullo G., Galligano F., Aiello F., 2017. Structure-activity relationships for the synthesis of selective cyclooxygenase 2 inhibitors: an overview (2009-2016). Med. Chem. Comm. 8, 492-500.

ChandRasekHARAN N. V., Dai H., RoOs K. L. T., Evanson N. K., TOMSIK J., ElTON T. S., SimMONS D. L., 2002. COX-3, a cyclooxygenase-1 variant inhibited by acetaminophen and other analgesic/antipyretic drugs: cloning, structure, and expression. Proc. Natl. Acad. Sci. USA 99, 13926-13931.

Cipollone F., FAZIA M. L., 2006. COX-2 and atherosclerosis. J. Cardiovasc. Pharmacol. 47, 26-36.

DANTZER R., 2009. Cytokine, sickness behavior, and depression. Immun. Allergy Clin. 29, 247-264.

Dantzer R., Konsman J. P., Bluthé R. M., KelLEY K. W., 2000. Neural and humoral pathways of communication from the immune system to the brain: parallel or convergent? Autonom. Neurosci. 85, 60-65.

De Paiva V. N., Lima S. N., Fernandes M. M., SONCINI R., ANDRADE C. A., GIUSTI-PAIVA A., 2010. Prostaglandins mediate depressive-like behaviour induced by endotoxin in mice. Behav. Brain Res. 215, 146-151.

DiNARELlo C. A., 1999. Cytokines as endogenous pyrogens. J. Infect. Diseases 179, 294-304.

DiNARELLO C. A., 2002. The IL-1 family and inflammatory diseases. Clin. Exp. Rheumatol. 20, 1-13.

DuNN A. J., 1988. Systemic interleukin-1 administration stimulates hypothalamic norepinephrine metabolism parallelling the increased plasma corticosterone. Life Sci. 43, 429-435.

DunN A. J., 2006. Effects of cytokines and infections on brain neurochemistry. Clin. Neurosci. Res. 6, 52-68.

FitZGERALD G. A., 2003. COX-2 and beyond: approaches to prostaglandin inhibition in human disease. Nat. Rev. Drug Discov. 2, 879-890.

Flavell S. W., GreEnBERG M. E., 2008. Signaling mechanisms linking neuronal activity to gene expression and plasticity of the nervous system. Ann. Rev. Neurosci. 31, 563-590.

FOKUNANG C. N., FOKUNANG E. T., FREDERICK K., NGAMENI B., NGADJUI B., 2018. Overview of non-steroidal anti-inflammatory drugs (NSAIDS) in resource limited countries. MedCrave Online J. Toxicol. 4, 5-13.

FUnK C. D., 2001. Prostaglandins and leukotrienes: advances in eicosanoid biology. Science 294, 1871-1875.

GröSCH S., NIEDERBERGER E., GEISSLINGER G., 2017. Investigational drugs targeting the prostaglandin E2 signaling pathway for the treatment of inflammatory pain. Expert Opin. Investigat. Drugs 26, 51-61.

HANSSON E., 2010. Long-term pain, neuroinflammation and glial activation. Scand. J. Pain 1, 67-72.

HERMAN J. P., Mueller N. K., Figueiredo H., 2004. Role of GABA and glutamate circuitry in hypothalamo-pituitary-adrenocortical stress integration. Ann. N Y Acad. Sci. 1018, 35-45.

HARRIS R. C., 2000. Cyclooxygenase-2 in the kidney. J. Am. Soc. Nephrol. 11, 2387-2394.

Hoshino T., NAmba T., TAKEHARA M., NAKAYA T., Sugimoto Y., ARAKI W., NARUMIYA S., SUZUKI T., MizUshima T., 2009. Prostaglandin E2 stimulates the production of amyloid beta peptides through internalization of the EP4 receptor. J. Biol. Chem. 284, 18493-18502.

Husband M., MEHTA V., 2013. Cyclo-oxygenase-2 inhibitors. Continuing education in anaesthesia. Crit. Care Pain 13, 131-135.

Ikeda-Matsuo Y., MiYata H., MizOGUChi T., OHAMA E., NAITO Y., UEMATSU S., AKIRA S., SASAKI Y., TANABE M., 2019. Microsomal prostaglandin $E$ synthase-1 is a critical factor in dopaminergic neurodegeneration in Parkinson's disease. Neurobiol. Disease 124, 81-92.

JoHANSSON J. U., WOODLING N. S, N., SHI J., ANDREASSON K. I., 2015. Inflammatory cyclooxygenase activity and PGE2 signaling in models of Alzheimer's disease. Curr. Immunol. Rev. $11,125-131$.

Kim J., VAish V., Feng M., Field K., ChatzistaMOU I., SHIM M., 2016. Transgenic expression of cyclooxygenase-2 (COX2) causes premature aging phenotypes in mice. Aging 8, 23922405.

Kis B., Isse T., Snipes J. A., Chen L., Yamashita H., UETA Y., BUSIJA D. W., 2006. Effects of LPS stimulation on the expression of prostaglandin carriers in the cells of the blood-brain and blood-cerebrospinal fluid barriers. J. Appl. Physiol. 100, 1392-1399.

KIECKER C., 2017. The origins of the circumventricular organs. J. Anat. 232, 540-553.

KITAOKA S., FURUYASHIKI T., NISHI A., SHUTO T., Koyasu S., Matsuoka T., Miyasaka M., GreenGARD P., NARUMIYA S., 2007. Prostaglandin E2 acts on EP1 receptor and amplifies both dopamine D1 and D2 receptor signaling in the striatum. J. Neurosci. 27, 12900-12907.

KOBRZYCKA A., RUDNICKI K., JABŁOŃSKI G., WIECZOREK M., 2017. Immunosensoryczne funkcje nerwu błędnego. Kosmos 66, 651-663.

KOBRZYCKA A., NAPORA P., PEARSON B. L., PIERZCHAEA-KOZIEC K., SZEWCZYK R., WIECZOREK M., 2019. Peripheral and central compensatory mechanisms for impaired vagus nerve function during peripheral immune activation. J. Neuroinflamm. 16, 1-18.

KoEBERle A., WerZ O., 2015. Perspective of microsomal prostaglandin E2 synthase-1 as drug target in inflammation-related disorders. Biochem. Pharmacol. 98, 1-15.

KOWALSKI M. L., MAKOWSKa J. S., Blanca M., BAvBeK S., BocheneK G., Bousquet J., Bousquet P., Celik G., Demoly P., Gomes E. R., NiŻANKOWSKA-MOGILNICKA E., ROMANO A., SANCHEZ-BORges M., SANZ M., TORRES M. J., DE WECK A., SZCZEKLIK A., BROCKOW K., 2011. Nadwrażliwość na niesteroidowe leki przeciwzapalne (NLPZ)-klasyfikacja, rozpoznawanie $i$ leczenie: przeglad EAACI/ENDA\# i GA2LEN/ HANNA. Alergia Astma Immunol. 16, 57-68.

LAZARUS M., 2006. The differential role of prostaglandin E2 receptors EP3 and EP4 in regulation of fever. Mol. Nutrit. Food Res. 50, 451455.

Levi G., MinghetTi L., Aloisi F., 1998. Regulation of prostanoid synthesis in microglial cells and effects of prostaglandin E2 on microglial functions. Biochimie 80, 899-904.

Li S., Ballou L. R., Morham S. G., Blatteis C. M., 2001. Cyclooxygenase-2 mediates the fe- 
brile response of mice to interleukin-1 $\beta$. Brain Res. 910, 163-173.

Lin T. Y., LU C. W., Wang C. C., Huang S., K., WANG S. J., 2014. Cyclooxygenase 2 inhibitor celecoxib inhibits glutamate release by attenuating the $P G E 2 / E P 2$ pathway in rat cerebral cortex endings. J. Pharmacol. Exp. Therapeut. 351, 134-145.

LOYNES C. A., LeE J. A., Robertson A. L., STEel M. J., Ellett F., Feng Y., LeVy B. D., Whyte M. K. B., RENSHAW S. A., 2018. PGE production at sites of tissue injury promotes an anti-inflammatory neutrophil phenotype and determines the outcome of inflammation resolution in vivo. Sci. Advances 4, 1-13.

MaingRet V., Barthet G., Deforges S., Jiang N., MulLE C., AMÉDÉE T., 2017. PGE -EP3 signaling pathway impairs hippocampal presynaptic long-term plasticity in a mouse model of Alz heimer's disease. Neurobiol. Aging 50, 13-24.

Marty V., Hachmane M., AmÉdÉE T., 2008. Dual modulation of synaptic transmission in the $\mathrm{nu}$ cleus tractus solitarius by prostaglandin E2 synthesized downstream of $I L \square 1 \beta$. Eur. J. Neurosci. 27, 3132-3150.

MASON B. L., PARIANTE C. M., JAMEL S., THOMAS S. A., 2010. Central nervous system (CNS) delivery of glucocorticoids is fine-tuned by saturable transporters at the blood-CNS barriers and nonbarrier regions. Endocrinology 151, 5294-5305.

Medeiros A., Peres-Buzalaf C., Fortino V. F., SEREZANI C. H., 2012. Prostaglandin $E_{2}$ and the suppression of phagocyte innate immune responses in different organs. Med. Inflamm. 2012, 1-13.

MinghetTI L., 2004. Cyclooxygenase-2 (COX-2) in inflammatory and degenerative brain diseases. J. Neuropathol. Exp. Neurol. 63, 901-910.

MinghetTi L., LeVI G. 1998. Microglia as effector cells in brain damage and repair: focus on prostanoids and nitric oxide. Progr. Neurobiol. 54, 99-125.

MinghetTI L., POCCHIARI M., 2007. Cyclooxygenase-2, prostaglandin E2, and microglial activation in prion diseases. Int. Rev. Neurobiol. 82, 265-275.

MinghetTi L., Polazzi E., Nicolin A., CRÉminon C., LEVI G., 1997. Up-regulation of cyclooxy genase-2 expression in cultured microglia by prostaglandin E2, cyclic AMP and non-steroidal anti-inflammatory drugs. Eur. J. Neurosci. 9, 934-940

MinghetTi L., Nicolini A., PolazZI E., Greco A., Perretti M., PARENTE L., Levi G., 1999 Down-regulation of microglial cyclo-oxygenase-2 and inducible nitric oxide synthase expression by lipocortin 1. Brit. J. Pharmacol. 126, 1307-1314.

NAKANISHI T., TAMAI I., 2017. Roles of organic anion transporting polypeptide 2A1 (OATP2A1/ SLCO2A1) in regulating the pathophysiological actions of prostaglandins. AAPS J. 20, 1-14.

NAM K. W., JE K. H., LEE J. H., HAN H. J., LEE H. J., KANG S. K., MAR W., 2003. Inhibition of COX-2 activity and proinflammatory cytokines (TNF-a and IL-1 $\beta$ ) production by water-soluble sub-fractionated parts from bee (Apis mellifera) venom. Arch. Pharm. Res. 26, 383-388.

OKA T., OKA K., SAPER C. B., 2003. Contrasting effects of $E$ type prostaglandin (EP) receptor agonists on core body temperature in rats. Brain Res. 968, 256-262.

OotsukA Y., Blessing W. W., STEINER A. A., RoMANOVSKY A. A., 2008. Fever response to in travenous prostaglandin E2 is mediated by the brain but does not require afferent va gal signaling. Am. J. Physiol. Regul. Integr. Comp. Physiol. 294, 1294-1303.

PAlumbo S., 2017. Pathogenesis and progression of multiple sclerosis: The role of arachidonic acid-mediated neuroinflammation. [W:] Multiple Sclerosis, Perspectives in Treatment and Pathogenesis. ZAGON I. S., MCLAUGHLIN P. J. (red.).Codon Publications Brisbane, 111-124.

PARENTE L., PERRETTI M., 2003. Advances in the pathophysiology of constitutive and inducible cyclooxygenases: two enzymes in the spotlight. Biochem. Pharmacol. 65, 153-159.

PARK J. Y., PILlinger M. H., ABRAMSON S. B., 2006. Prostaglandin E2 synthesis and secretion: the role of PGE2 synthases. Clin. Immunol. 119, 229-240.

PECCHI E., DALlaPorTA M., JEAN A., THIRION S. TROADEC J. D., 2009. Prostaglandins and sickness behavior: old story, new insights. Physiol. Behav. 97, 279-292.

PerRone G. M., Scilimati A., Simone L., Vitale P., 2010. Selective COX-1 inhibition: A therapeutic target to be reconsidered. Curr. Med. Chem. 17, 3769-3805.

Rajagopalan G., Tilahun A. Y., Asmann Y. W., DAVID C. S., 2009. Early gene expression changes induced by the bacterial superantigen, staphylococcal enterotoxin $B$ and its modulation by a proteasome inhibitor. Physiol. Genomics 37, 279-293.

Reardon C., Murray K., LomaX A. E., 2018. Neuroimmune communication in health and disease. Physiol. Rev. 98, 2287-2316.

Ren L., Yi J., Yang J., Li P., Cheng X., MaO P., 2018. Nonsteroidal anti-inflammatory drugs use and risk of Parkinson disease: A dose-response meta-analysis. Medicine 97, 1-8.

REgUŁA J., WOCIAL T., KRASZEWSKA E., BUTRUK, E., 2011. Stosowanie niesteroidowych leków przeciwzapalnych $w$ Polsce - badanie ankietowe u 38 tysiecy chorych. Gastroenterol. Klin. Post. Stand. 3, 72-78.

RicciotTi E., FitzGERALD G. A., 2011. Prostaglandins and inflammation. Arterioscler. Thromb. Vasc. Biol. 31, 986-1000.

Rimon G., SidHU R. S., LAUVER D. A., LEE J. Y. SHARMa N. P., YuAN C., Frieler R. A., TRIEVEL R. C., LuCChesi B. R., SMith W. L., 2010. Coxibs interfere with the action of aspirin by binding tightly to one monomer of cyclooxygenase-1. Proc. Natl. Acad. Sci. USA 107, 28-33.

RIVEST S., 2010. Interactions between the immune and neuroendocrine systems. Progr. Brain Res. 181, 43-53.

Rouzer C. A., MARnetT L. J., 2009. Cyclooxygenases: structural and functional insights. J. Lipid Res. 50, 29-34.

SAMBORSKI W., NiKLAS A., FILIPIAK K. J., KACZMARCZYK J., DOBROWOLSKA-ZACHWIEJA A., TYKARSKI A., 2017. Niesteroidowe leki przeciwzapalne a powikłania sercowo-naczyniowe $i$ gastroenterologiczne - algorytm wyboru. Choroby Serca i Naczyń 14, 238-247.

Sander W. J., O’NeIll H. G., POHL C. H., 2017. Prostaglandin E2 as a modulator of viral infections. Front. Physiol. 8, 1-17.

Saper C. B., Romanovsky A. A., Scammell T. E., 2012. Neural circuitry engaged by prostaglandins during the sickness syndrome. Nat. Neurosci. 15, 1-20.

Schlachetzki J. C., Fiebich B. L., HaAke E., De Oliveira A. C., CANDElario-Jalil E., HeneKA M. T., HÜLL M., 2010. Norepinephrine enhances the LPS-induced expression of COX-2 and 
secretion of PGE 2 in primary rat microglia. J. Neuroinflamm. 7, 1-10.

SEO M. J., OH D. K., 2017. Prostaglandin synthases: molecular characterization and involvement in prostaglandin biosynthesis. Progr. Lipid Res. 66, 50-68.

SHAHRASBI M., MOVAHED M. A., DADRAS O. G. DARAEI B., ZARGHI A., 2018. Design, synthesis and biological evaluation of new Imidazo (2, 1-B) thiazole derivatives as selective COX2 inhibitors. Iranian J. Pharmaceut. Res. 17, $87-92$.

SHINPO K., HiRAi Y., MAEZAWA H., TOTSUKA Y., FUNAHASHI M. 2012. The role of area postrema neurons expressing $H$-channels in the induction mechanism of nausea and vomiting. Physiol. Behav. 1071, 98-103.

ST-JACQUES B., MA W., 2014. Peripheral prostaglandin E2 prolongs the sensitization of nociceptive dorsal root ganglion neurons possibly by facilitating the synthesis and anterograde axonal trafficking of EP4 receptors. Exp. Neurol. 261, 354-366.

SKOWRON-CENDRZAK A., 1993. Integralność układów nerwowego i odpornościowego. Kosmos. 42, 285-307.

SOSZYŃSKI D., 2004. Sickness behavior - mechanizmy powstania $i$ znaczenie. Post. Hig. Med. Dośw. 58, 74-82.

Stenken J. A., Poschenrieder A. J., 2015. Bioanalytical chemistry of cytokines - A review. Anal. Chim. Acta 853, 95-115.

STRAUSS K. I., 2008. Antiinflammatory and neuroprotective actions of COX2 inhibitors in the injured brain. Brain Behav. Immun. 22, 285298.

Strle K., Zhou J. H., Shen W. H., Broussard S. R., JOHNSON R. W., FREUND G. G., DANTZER R., Kelley K. W., 2001. Interleukin-10 in the brain. Crit. Rev. Immunol. 21, 427-449.

Sugimoto Y., NARUMiYA S., 2007. Prostaglandin E receptors. J. Biol. Chem. 282, 11613-11617.

Teismann P., Tieu K., Choi D. K., Wu D. C., NAINI A., HUNOT S., VILA M., JACKSON-LEWIS V., PRZEDBorski S., 2003. Cyclooxygenase-2 is instrumental in Parkinson's disease neurodegeneration. Proc. Natl. Acad. Sci. USA 100, 5473-5478.

TRACEY K. J., 2007. Physiology and immunology of the cholinergic antiinflammatory pathway. J. Clin. Invest. 117, 289-296.

TSUCHIYA H., OKA T., NAKAMURA K., ICHIKAWA A, SAPER C. B., Sugimoto Y., 2008. Prostaglandin E2 attenuates preoptic expression of GAB$A A$ receptors via $E P 3$ receptors. J. Biol. Chem. 283, 11064-11071.
UFNAL M., WOLYNCZYK-GMAJ D., 2011. The brain and cytokines-the mutual origin of depression, obesity and cardiovascular diseases? Post. Hig. Med. Dośw. 65, 228-235.

WallaCE J. L., 2000. How do NSAIDs cause ulcer disease? Best Pract. Res. Clin. Gastroenterol. 14, 147-160.

Wang P., Guan P. P., Wang T., Yu X., Guo J. J., WANG Z. Y., 2014. Aggravation of Alzheimer's disease due to the COX-2-mediated reciprocal regulation of $I L-1 \beta$ and $A \beta$ between glial and neuron cells. Aging Cell 13, 605-615.

Woodling N. S., Colas D., Wang Q., Minhas P., Panchal M., Liang X., MaHTRE A. D., BRoWN H., Ko N., ZagOl-IKAPITTE I., VAN DER HART M., Khroyan T. V., Chuluun B., Priyam P, G., Milne G. L., Rassoulpour A., Boutaud O., MANNING-BoĞ A. B., HELler C., ANDREASSON K. I., 2016. Cyclooxygenase inhibition targets neurons to prevent early behavioural decline in Alzheimer's disease model mice. Brain 139, 2063-2081.

WOROŃ J., WORDLICZEK J., DOBROGOWSKI J., 2011. Porównanie niesteroidowych leków przeciwzapalnych (NLPZ). Medycyna po Dyplomie 6, 55-63.

WRIGHT J. M., 2002. The double-edged sword of COX-2 selective NSAIDs. Canad. Med. Assoc. J. 167, 1131-1137.

WU Z., NAKANISHI H., 2011. Phosphatidylserine-containing liposomes: potential pharmacological interventions against inflammatory and immune diseases through the production of prostaglandin E 2 after uptake by myeloid derived phagocytes. Arch. Immunol. Therap. Exp. 59, 195-201.

VARDEH D., Wang D., Costigan M., Lazarus M., SAPER C. B., WOOlF C. J., FitzGerald G. A, SAMAD T. A., 2009. COX2 in CNS neural cells mediates mechanical inflammatory pain hypersensitivity in mice. J. Clin. Invest. 119, 287 294.

YANG H., Chen C., 2008. Cyclooxygenase-2 in synaptic signaling. Curr. Pharmaceut. Design $14,1443-1451$.

Zhang Y. H., Lu J., Elmquist J. K., Saper C. B., 2003. Specific roles of cyclooxygenase-1 and cyclooxygenase-2 in lipopolysaccharide-induced fever and Fos expression in rat brain. J. Compar. Neurol. 463, 3-12.

Zhu P., Genc A., Zhang X., Zhang J., BaZAN N. G., CHEN C., 2005. Heterogeneous expression and regulation of hippocampal prostaglandin E2 receptors. J. Neurosci. Res. 81, 817-826. 
KOSMOS Vol. 69, 2, 287-300, 2020

Pawee NAPora, ANNA Kobrzycka, Marek WiEcZOREK

Department of Neurobiology, Faculty of Biology and Environmental Protection, University of Eódź, 141/143 Pomorska Str., $90-236$ Łódź, E-mail: pawel.napora@unilodz.eu, marek.wieczorek@biol.uni.lodz.pl

\section{PROSTAGLANDIN E2 AS A COMMUNICATION MOLECULE BETWEEN NERVOUS AND IMMUNE SYSTEM}

\section{Summary}

The exchange of information between an excited immune system and the central nervous system (CNS) ensures that the homeostasis of the body is maintained. One of the main paths responsible for this communication is the humoral one. It is represented by compounds released by immune cells and damaged tissues. The molecules significantly involved in the aforementioned communication process are prostaglandins, especially prostaglandin E2 ( $\left.\mathrm{PGE}_{2}\right)$, resulting from the activity of cyclooxygenases. $\mathrm{PGE}_{2}$ penetrates all body barriers, including the blood-brain barrier, and what is more, CNS-specific receptors have been confirmed in the CNS. Through them, PGE ${ }_{2}$ modulates the activity of neurotransmission systems in the CNS, which consequently induces the body's complex immune mechanisms. Ultimately, the infection is effectively neutralized while inhibiting the activity of the over-excited immune system. The effects caused by $\mathrm{PGE}_{2}$ are weakened or completely eliminated by the use of certain cyclooxygenase inhibitors. This work is a summary of current information on information exchange processes between an induced immune system and the CNS via $\mathrm{PGE}_{2}$.

Key words: cyclooxygenases, immune system, nervous system, neuroimmunomodulation, prostaglandin E2 